\title{
Peranan Padang Lamun Selatan Bali Sebagai Pendukung Kelimpahan Ikan di Perairan Bali
}

\author{
Elok Faiqoh a*, Dwi Budi Wiyanto a, I Gede Budi Astrawan a \\ a Program Studi Ilmu Kelautan, Fakultas Kelautan dan Perikanan, Universitas Udayana, Kampus UNUD Bukit Jimbaran, Bali 80361, Indonesia \\ * Penulis koresponden. Tel.: +62-8223-7283-783 \\ Alamat e-mail: elokfaiqoh@unud.ac.id
}

Diterima (received) 20 Desember 2016; disetujui (accepted) 31 Januari 2017; tersedia secara online (available online) 1 Februari 2017

\begin{abstract}
Seagrass ecosystem is providing feeding ground, nursery ground, spawning ground, habitat and shelter area. The threat of physical destruction such as the reclamation, pollution, sedimentation and tourism activities decreasing the diversity and the abundance of fishery commodities. The purpose of this study was to describe the condition of seagrass, determine the composition and abundance of seagrass fish in the three Southern coast of Bali and assess the association of fish-sea grass. Samples were taken from three coastal areas, Samuh, Shindu and Serangan coastal area. The results are in Samuhthere are 6 types of seagrass, in Shindu there are 7 types and in Serangan there are three types, whichdominates with Cymodocea rotundata and Syringodium isoetifolium. From the three coastal areas,we found 21 families of fish, where the family Pomacentridaehas the highest species abundance in Samuh, Apogon sp in Serangan and Terapon sp. found in Shindu. We can see the interaction between the seagrass ecosystems of coral reefs in the waters of South Bali and ecological role of seagrass from the family and species of fish.
\end{abstract}

Keywords: seagrass role; fish; southern Bali

\begin{abstract}
Abstrak
Lamun berperan untuk menyediakan makanan, tempat pemijahan, tempat pengasuhan larva dan habitat bagi banyak organisme laut khususnya ikan. Ancaman perusakan fisik terhadap ekosistem lamun seperti reklamasi pantai, pencemaran, sedimentasi dan aktivitas pariwisata menimbulkan kekhawatiran akan menurunnya keragaman dan kelimpahan komoditi perikanan. Tujuan penelitian ini adalah untuk mendeskripsikan kondisi padang lamun, mengetahui komposisi dan kelimpahan ikan padang lamun di tiga pantai pesisir Selatan Bali dan menilai asosiasi ikan-lamun tersebut. Sampel diambil dari 3 pantai, pantai Samuh, Pantai Shindu dan Pantai Serangan. Hasilnya di Pantai Samuh terdapat 6 jenis lamun, pada Pantai Shindu terdapat 7 jenis dan di Pantai Serangan tiga jenis yaitu dengan Cymodocea rotundata dan Syringodium isoetifolium yang mendominasi. Dari padang lamun tiga pantai daerah selatan Bali ditemukan 21 family ikan, dimana family Pomacentridae yang memiliki jenis species terbanyak Kelimpahan terbesar di Pantai Samuh dan Pantai Serangan adalah jenis Apogon sp, sedangkan di Pantai Shindu adalah jenis Terapon sp. Ikan yang di temukan di Padang Lamun Selatan Bali. Dari jenis dan family yang ditemukan, dapat dilihat adanya interaksi antara ekosistem lamun dengan terumbu karang di Perairan Selatan Bali dan peranan lamun secara ekologis berjalan baik.
\end{abstract}

Kata Kunci: peranan lamun; ikan; selatan Bali

\section{Pendahuluan}

Ekosistem lamun bersama dengan ekosistem mangrove dan terumbu karang merupakan ekosistem penyangga dan sangat penting di daerah pesisir (Nontji, 2009). Kerapatan yang tinggi dan bentuk terlindung menyebabkan lamun berfungsi sebagai penyedia makanan langsung bagi organisme herbivora dan tempat berlindung bagi organisme kecil (Heck et al., 2008; Rappe., et al., 2013) sehingga berkontribusi besar terhadap 
kelimpahan ikan di laut (Rappe, 2010). Peranan lamun yang besar dalam hal menjaga keberlangsungan hidup biota khususnya ikan, juga membantu masyarakat sekitar dalam menopang kebutuhan pangan (Nordlund et al., 2010) sehingga menjadi perhatian pemerintah dengan menyebutkan Kelautan dan Perikanan merupakan sektor yang dapat memberikan kontribusi dalam pembangunan pangan, sehingga terdapat rekomendasi untuk melakukan konservasi ekosistem pantai dalam rangka melestarikan daerah pemijahan, daerah asuhan dan habitat bagi Ikan dan biota laut lainnya (Menristek, 2010). Selain itu di dalam lingkungannya, lamun berperan besar dalam pemurnian air laut dan membersihkan pencemaran yang akan masuk ke laut (Campagne et al., 2015) .

Salah satu lokasi padang lamun di Bali yang sering dimanfaatkan oleh masyarakat sekitar adalah di daerah Selatan Bali. Padang lamun daerah Selatan Bali, tersebar tidak merata dari sepanjang Pantai Sanur, Pantai Serangan, Pantai Tanjung Benoa dan Pantai Nusa Dua. Degradasi ekosistem pesisir Selatan Bali dan perbedaan karakteristik pantai pesisir Selatan Bali menimbulkan kekhawatiran akan menurunnya keragaman dan kelimpahan komoditi perikanan. Karena itu, data dasar dari keberadaan ikan di padang lamun pantai selatan Bali, perlu dilakukan sebagai upaya untuk mempertahankan kelangsungan hidup ikan di perairan Bali dalam jangka panjang.

\section{Metode Penelitian}

\subsection{Lokasi Penelitian}

Penelitian ini dilakukan di Pulau Bali bagian selatan. Pulau Bali bagian selatan memiliki keraaman lamun dan ikan karang yang cukup tinggi. Selain itu, Pulau Bali bagian selatan juga merupakan daerah pusat kegiatan pariwisata untuk Provinsi Bali. Dalam studi ini, Pulau Bali bagian selatan sebagai lokai pengambilan sampel lamun dan ikan diwakili oleh daerah Pantai Sanur, Pantai Serangan dan Pantai Samuh (Gambar 1).

\subsection{Pengambilan data}

Data yang diambil ada dua macam, data vegetasi lamun dan data kelimpahan ikan.

\subsubsection{Pengambilan data lamun}

Metode pengambilan data lamun dengan "Line Intercept Transect". Langkah-langkah pengukuran struktur vegetasi lamun adalah transek dipasang tegak lurus garis pantai, dari batas mulai lamun ditemukan hingga lamun tidak teramati lagi. Setiap 10 meter di garis transek diletakkan kuadrat (Gambar 2) dengan ukuran 50x50 cm lakukan sampai sepanjang $100 \mathrm{~m}$.

\subsubsection{Pengambilan data ikan}

Sampel ikan diperoleh menggunakan jaring pantai yang ditarik sejajar garis transek. Ikan yang

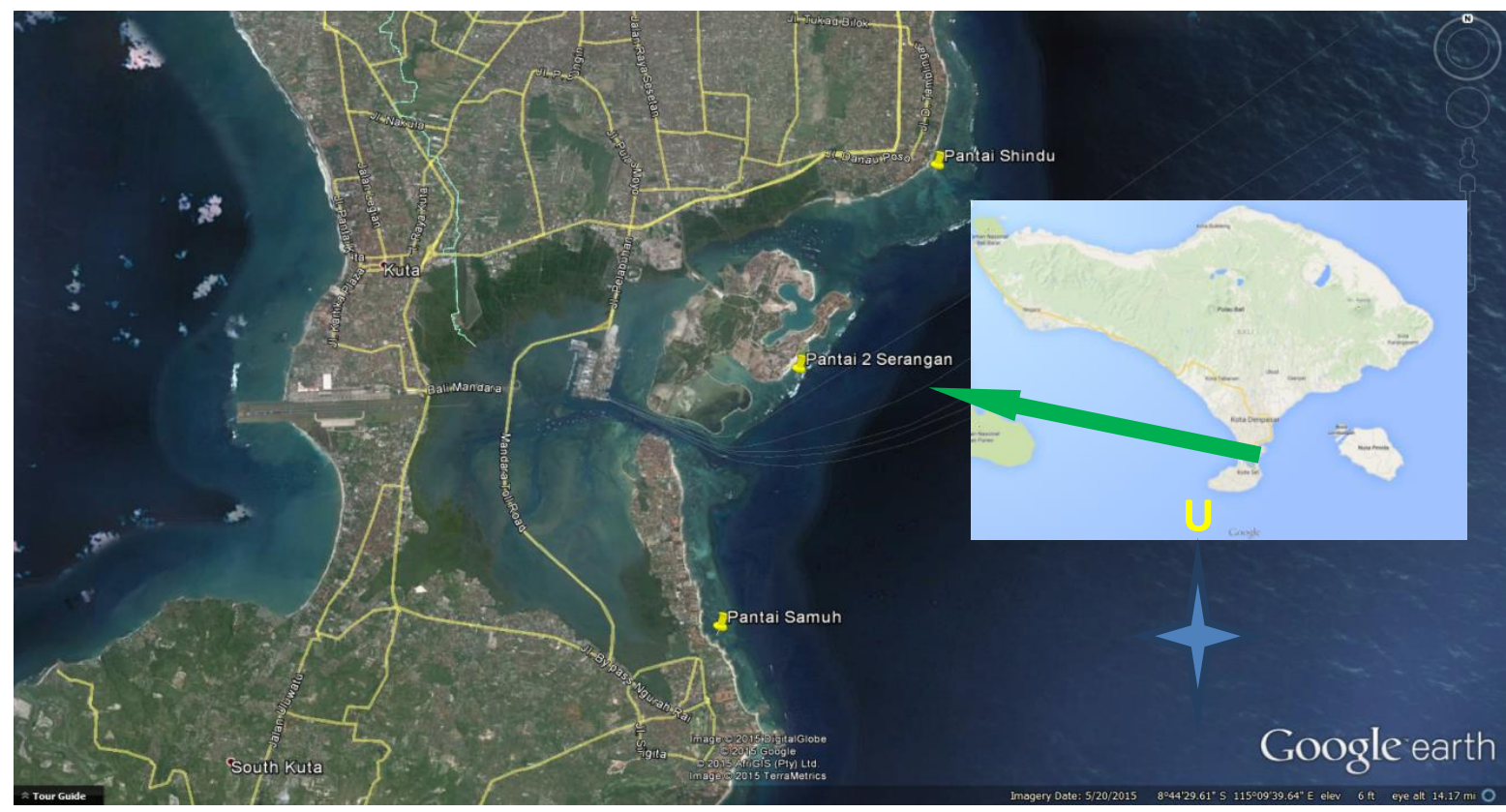

Gambar 1. Lokasi penelitian. 
tertangkap, apabila bisa diidentifikasi secara langsung, dicatat nama jenis dan jumlahnya. Bila belum bisa diidentifikasi, ikan dikelompokkan berdasarkan kemiripan, dihitung jumlahnya, lalu dua sampel dimasukkan ke dalam plastik sampel dan diberi formalin, kemudian dibawa ke laboratorium untuk diidentifikasi.

\subsection{Analisa data}

Analisa data yang dihitung adalah kelimpahan lamun, indeks ekologi lamun, kelimpahan ikan dan indeks asosiasi ikan dan lamun.

\subsubsection{Kelimpahan}

Kelimpahan adalah jumlah individu per satuan luas atau volume area yang di hitung menggunakan persamaan (Hejda et al., 2009):

$$
D i=\frac{n i}{A}
$$

dimana $D i$ adalah kelimpahan (ind $/ \mathrm{m}^{2}$ ); $n i$ adalah jumlah individu (ind); dan $A$ adalah luas area sampling $\left(\mathrm{m}^{2}\right)$.

\subsubsection{Indeks ekologi}

a. Indeks keanekaragaman

Indeks keanekaragaman $\left(H^{\prime}\right)$ dapat menunjukan keseimbangan keanekaragaman dalam suatu pembagian jumlah individu tiap jenis, dimana indeks ini dapat dihitung menggunakan persamaan (Hejda et al., 2009):

$$
H^{\prime}=\sum p i \operatorname{Ln}(p i) \Rightarrow p i=\frac{n i}{N}
$$

dimana $N$ adalah jumlah total individu (ind). Tinggi atau rendahnya keanekaragaman spesies dapat dilihat dengan menggunakan $H^{\prime}$, dimana bila $H^{\prime}<1$ dikategorikan sebagai keanekaragaman rendah; bila $H^{\prime} \geq 1$ dan $<3$ dikategorikan sebagai keanekaragaman sedang; dan bila $H^{\prime} \geq 3$ dikategorikan sebagai keanekaragaman tinggi.

\section{b. Indeks keseragaman}

Indeks keseragaman (E) adalah komposisi individu tiap spesies yang terdapat dalam suatu komunitas, dimana dapat dihitung menggunakan persamaan (Hejda et.al.,2009) :

$E=\frac{H^{\prime}}{H m a k s} \Rightarrow H m a k s=L n S$

dimana $S$ adalah jumlah spesies. Tinggi atau rendahnya keseragaman jenis dapat dilihat dengan menggunakan $E$, dimana bila $E \leq 0,4$ dikategorikan sebagai keseragaman rendah; bila $E>0,4$ dan $\leq 0,6$ dikategorikan sebagai keseragaman sedang; dan bila $E>0,6$ dikategorikan sebagai keseragaman

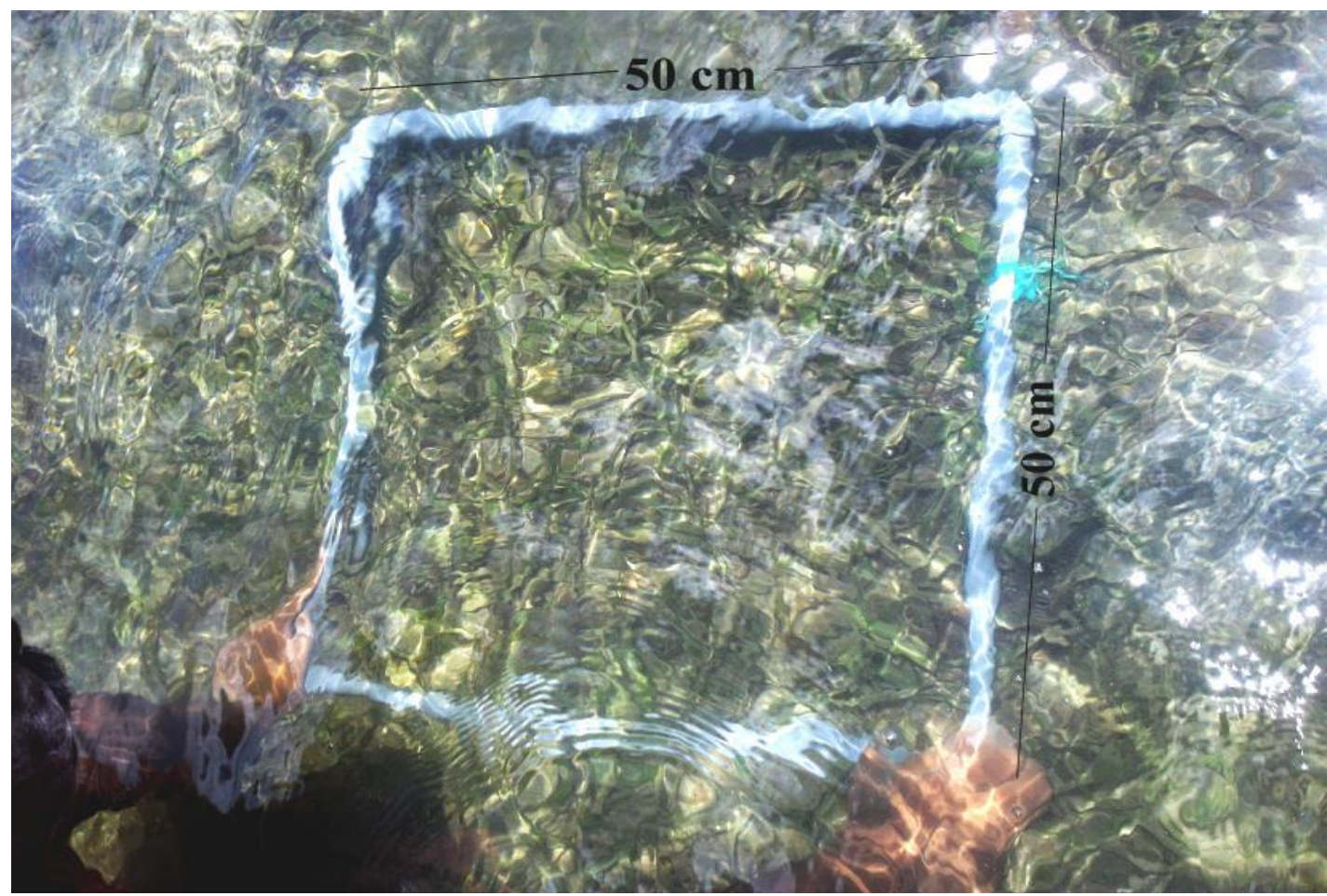

Gambar 2. Transek kuadrat sampel lamun. 

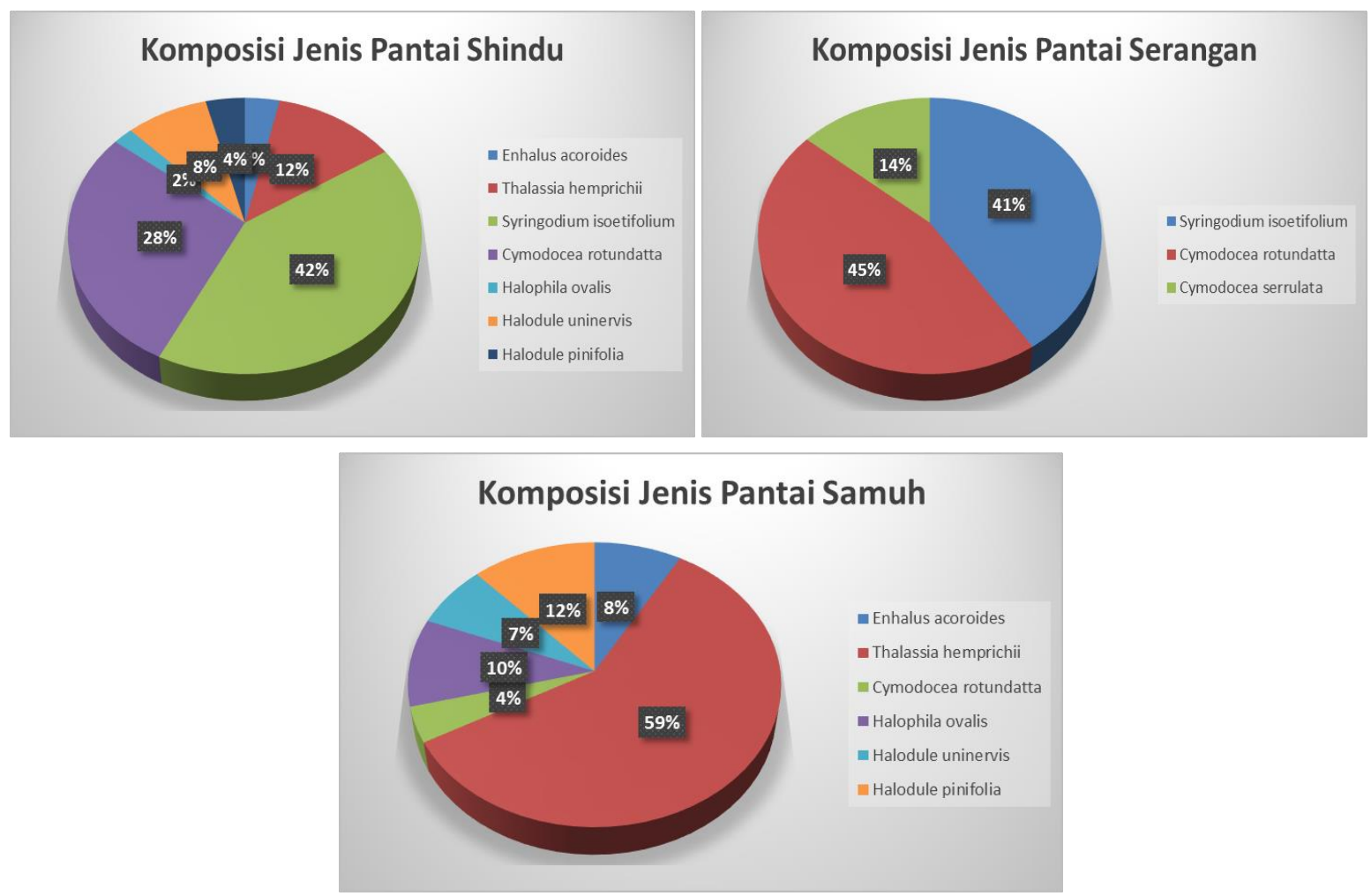

Gambar 3. Diagram persentase komposisi jenis lamun di Pantai Shindu, Pantai Serangan dan Pantai Samuh

tinggi.

\section{c. Indeks dominansi}

Indeks dominansi (C) memberikan gambaran tentang dominansi organisme dalam suatu komunitas ekologi sehingga dapat menerangkan bilamana suatu jenis lebih banyak terdapat selama pengambilan data. Nilai $C$ dapat dihitung menggunakan persamaan (Hejda et.al.,2009):

$$
C=\sum p i^{2} \Rightarrow p i=\frac{n i}{N}
$$

Dominansi suatu organisme dapat dikategorikan tinggi atau rendahnya berdasarkan nilai $C$, dimana bila nilai $C \leq 0,3$ dikategorikan sebagai dominansi rendah; bila nilai $C>0,3$ dan $\leq 0,6$ dikategorikan sebagai dominansi sedang; dan bila nilai $C>0,6$ dikategorikan sebagai dominansi tinggi.

\subsubsection{Indeks asosiasi}

Pengujian asosiasi antar 2 jenis/spesies didasarkan pada ada/hadir atau tidaknya spesies dalam suatu penarikan contoh (tabel kontegensi 2x2 (Tabel 2)). Tabel 2 menunjukan $a$ adalah jumlah contoh dimana terdapat kedua spesies; $b$ adalah jumlah contoh dimana hanya terdapat spesies $\mathrm{A} ; c$ adalah jumlah contoh dimana hanya terdapat spesies B; dan $d$ adalah jumlah contoh dimana kedua spesies tidak terdapat. Sementara itu, penentuan tipe asosiasi dihitung menggunakan persamaan 5 (Bass at al., 2013).

Tabel 1

Tabel kontigensi matriks 2x2

\begin{tabular}{llcc}
\multirow{2}{*}{ Tabel kontingensi } & \multicolumn{2}{c}{ Spesies B } \\
\cline { 2 - 4 } & & Ada & Tidak ada \\
\cline { 2 - 3 } Spesies A & Ada & $a$ & $b$ \\
& Tidak ada & $c$ & $d$ \\
\hline
\end{tabular}

$E(a)=\frac{(a+b)(a+c)}{a+b+c+d}$

dimana $E(a)$ adalah nilai harapan independen. Bengen (2000) mengkkasifikasi tipe asosiasi berdasarkan nilai E(a), dimana suatu asosiasi disebut positif bila nilai observasi $a>E(a)$, atau kenyataan bahwa kedua spesies lebih sering muncul bersama daripada nilai harapan independen. Sedangkan suatu asosiasi disebut negatif bila nilai observasi a $<\mathrm{E}(\mathrm{a})$, atau kenyataan bahwa kedua spesies lebih sering tidak hadir bersama daripada nilai harapan independen. 
Sementara itu tingkat asosiasi antar 2 jenis/spesies organisme dapat diukur dengan menghitung indeks asosiasi Jaccard (JI) menggunakan persamaan (6) (Bass at al., 2013) dan pengklasifikasian nilai $J I$ didasarkan oleh nilai asosiasi seperti yang tertera pada Tabel 2.

$J I=\frac{a}{a+b+c}$

Tabel 2

Klasifikasi kelas indeks asosiasi berdasarkan nilai JI

\begin{tabular}{cll}
\hline No. & Indeks Asosiasi & Keterangan \\
\hline 1 & $1.00-0.75$ & Sangat Tinggi \\
2 & $0.74-0.49$ & Tinggi \\
3 & $0.48-0.23$ & Rendah \\
4 & $<0.22$ & Sangat Rendah \\
\hline
\end{tabular}

\section{Hasil}

\subsection{Komposisi jenis lamun}

Persentase komposisi jenis yang didapatkan, dapat dilihat pada Gambar 3. Pada gambar tersebut terlihat komposisi jenis lamun yang didapatkan Pantai Samuh terdapat 6 jenis lamun, Enhalus acoroides, Thalassia hemprichii, Cymodocea rotundata, Halophila ovalis, Halodule uninervis, Halodule pinifolia.

Komposisi jenis lamun yang didapatkan pada Pantai Shindu terdapat 7 jenis Enhalus acoroides, Thallasia hemprichii, Syringodium isoetifolium, Cymodocea rotundata, Halophila ovalis, Halodule uninervis, H. pinifolia; dan komposisi jenis lamun yang didapatkan di Pantai Serangan terdapat tiga jenis yaitu Syringodium isoetifolium, Cymodocea rotundata, C. serrulata.

\subsection{Kerapatan lamun}

Jenis lamun Cymodocea rotundata dan Syringodium isoetifolium banyak ditemukan di Pantai Serangan. Di Pantai Shindu, lamun yang banyak ditemukan adalah Syringodium isoetifolium dan Cymodocea rotundata, sedangkan di Pantai Samuh, jenis Thalassia hemprichii paling banyak dijumpai. Hasil lebih lengkap dapat dilihat pada Tabel 3.

\subsection{Indeks ekologi lamun}

Indeks Ekologi dipakai untuk melihat kestabilan komunitas lamun. Indeks ekologi dari komunitas lamun di Pantai Serangan, Shindu dan Samuh dapat dilihat pada Gambar 4.

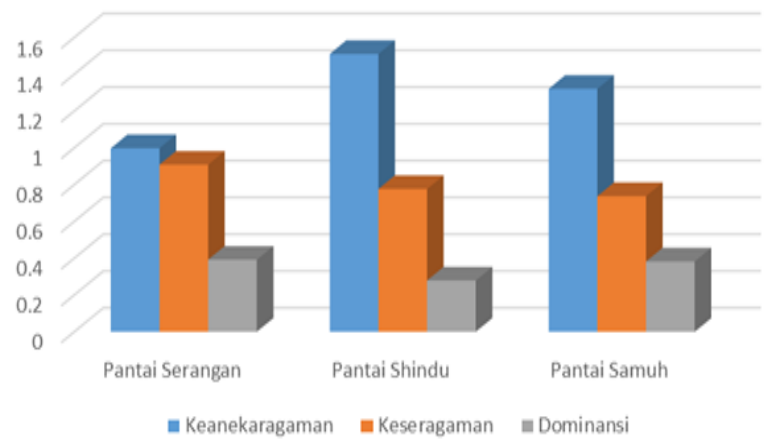

Gambar 4. Grafik indeks ekologi Pantai Serangan, Shindu dan Samuh.

Indeks keseragaman yang didapat pada semua pantai berada pada nilai diatas 0,6 dimana ini berarti keseragaman individu tinggi dan nilai indeks dominansi untuk Pantai Shindu dibawah 0,3 yang berarti dominansi rendah, atau tidak ada species. Gambar 4 memperlihatkan Pantai Shindu dan Pantai Samuh memiliki nilai keanekaragaman

Tabel 3

Kerapatan lamun Pantai Serangan, Shindu dan Samuh

\begin{tabular}{|c|c|c|c|c|c|c|c|c|c|c|}
\hline \multirow{2}{*}{ No } & \multirow{2}{*}{ Jenis Lamun } & \multicolumn{3}{|c|}{ Pantai Serangan } & \multicolumn{3}{|c|}{ Pantai Shindu } & \multicolumn{3}{|c|}{ Pantai Samuh } \\
\hline & & Stasiun 1 & Stasiun 2 & Rata-rata & Stasiun 1 & Stasiun 2 & Rata-rata & Stasiun 1 & Stasiun 2 & Rata-rata \\
\hline 1 & Enhalus acoroides & 0 & 0 & 0 & 3 & 5 & 4 & 6 & 5 & 6 \\
\hline 2 & Thalassia hemprichii & 0 & 0 & 0 & 16 & 13 & 14 & 16 & 66 & 41 \\
\hline 3 & Syringodium isoetifolium & 44 & 74 & 59 & 7 & 89 & 48 & 0 & 0 & 0 \\
\hline 4 & Cymodocea rotundatta & 57 & 74 & 66 & 35 & 31 & 33 & 6 & 0 & 3 \\
\hline 5 & Halophila ovalis & 0 & 0 & 0 & 2 & 2 & 2 & 12 & 2 & 7 \\
\hline 6 & Halodule uninervis & 0 & 0 & 0 & 19 & 0 & 10 & 10 & 0 & 5 \\
\hline 7 & Cymodocea serrulata & 40 & 0 & 20 & 0 & 0 & 0 & 0 & 0 & 0 \\
\hline 8 & Halodule pinifolia & 0 & 0 & 0 & 1 & 8 & 5 & 8 & 9 & 8 \\
\hline & Jumlah & 141 & 148 & 145 & 82 & 148 & 115 & 58 & 83 & 70 \\
\hline
\end{tabular}




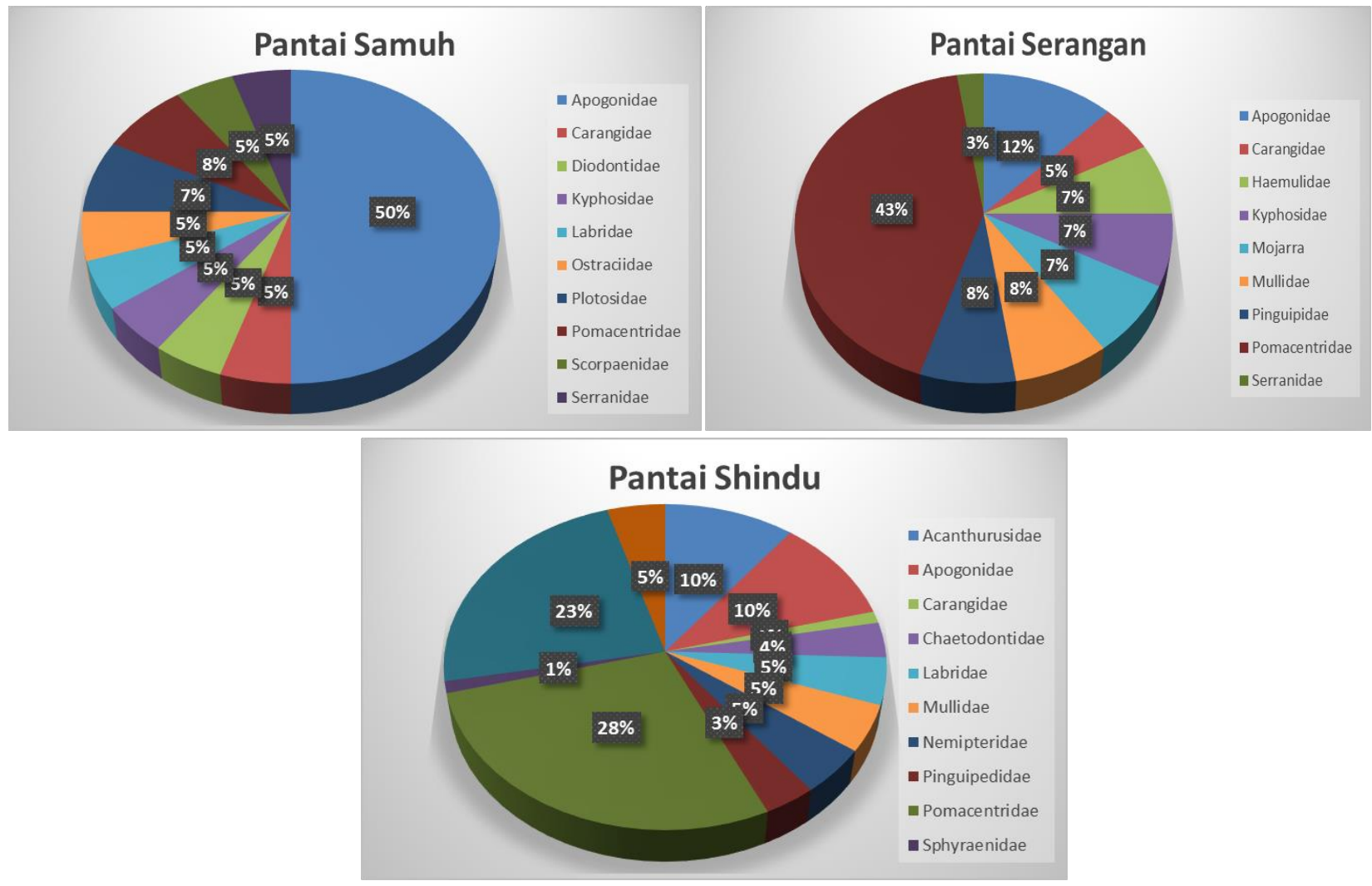

Gambar 5. Persentase komposisi jenis ikan di Pantai Shindu, Pantai Serangan dan Pantai Samuh

diatas 1 dan dibawah 3 dimana ini berarti keanekaragaman lamun di perairan Pantai tersebut sedang, sedangkan nilai indeks keanekaragaman Pantai Serangan lebih kecil dari 1, yang berarti keanekaragaman lamunnya rendah. yang mendominasi, sedangkan pada Pantai Serangan dan Pantai Samuh nilai indeks dominansi berada diatas 0,3, atau dengan kata lain dominansi di tiga stasiun tersebut sedang, berarti ada species yang mendominasi walau tidak besar jumlah dominansinya.

\subsection{Komposisi jenis dan kelimpahan ikan}

Komposisi ikan karang yang terdiri dari 21 Famili dengan family yang didapatkan species terbanyak adalah Family Pomacentridae, yaitu sebanyak 13 species. Jumlah total species dari tiga pantai adalah 37 species dengan masing-masing pantai, Pantai Samuh ditemukan 10 jenis, Pantai Serangan ditemukan 14 jenis dan di Pantai Shindu ditemukan 19 jenis. Persentase yang dihasilkan dapat dilihat pada Gambar 5.

Kelimpahan ikan total terbesar didapatkan pada Pantai Shindu yaitu $0.172 \mathrm{ind} / \mathrm{m}^{2}$, kemudian Pantai Samuh sebanyak 0.08 ind $/ \mathrm{m}^{2}$ dan Pantai Serangan sebanyak $0.016 \mathrm{ind} / \mathrm{m}^{2}$ (Gambar 6). Dari hasil tersebut terlihat bahwa Pantai Shindu didapatkan paling banyak jumlah komposisi jenis dan total kelimpahan ikan daripada 2 pantai lainnya. Jenis ikan yang didapatkan di tiga pantai selatan Bali ini masih dalam ukuran juvenile dan 19 ikan merupakan ikan target (ikan yang dicari nelayan untuk di konsumsi).

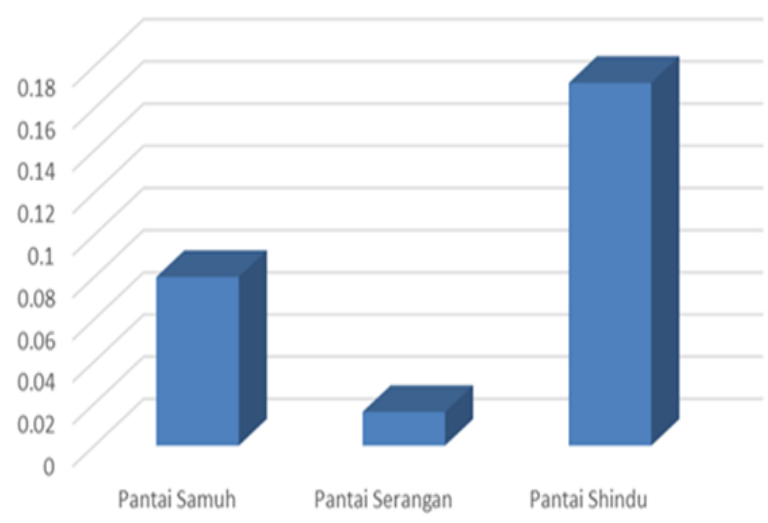

Gambar 6. Jumlah total kelimpahan ikan di Pantai Samuh, Serangan, dan Shindu.

\subsection{Indeks asosiasi ikan dan lamun}

Bentuk asosiasi ikan dengan padang lamun disajikan pada Tabel 4. Berdasarkan Tabel 4 diketahui bahwa lamun dengan Ikan di pantai 
Tabel 4

Indeks asosiasi ikan dan lamun

\begin{tabular}{|c|c|c|c|c|c|}
\hline Asosiasi & Indeks Asosiasi & Ket. & $\begin{array}{c}\text { Pantai } \\
\text { Serangan }\end{array}$ & $\begin{array}{l}\text { Pantai } \\
\text { Shindu }\end{array}$ & $\begin{array}{l}\text { Pantai } \\
\text { Samuh }\end{array}$ \\
\hline \multirow{4}{*}{ Positif } & $1.00-0.75$ & ST & 0 & 0 & 0 \\
\hline & $0.74-0.49$ & $\mathrm{~T}$ & 12 & 19 & 16 \\
\hline & $0.48-0.23$ & $\mathrm{R}$ & 0 & 0 & 0 \\
\hline & $<0.22$ & SR & 0 & 0 & 0 \\
\hline \multirow{4}{*}{ Negatif } & $1.00-0.75$ & ST & 0 & 0 & 0 \\
\hline & $0.74-0.49$ & $\mathrm{~T}$ & 0 & 0 & 0 \\
\hline & $0.48-0.23$ & $\mathrm{R}$ & 0 & 0 & 0 \\
\hline & $<0.22$ & SR & 0 & 0 & 0 \\
\hline \multirow{4}{*}{ Tidak Jelas } & $1.00-0.75$ & ST & 24 & 144 & 32 \\
\hline & $0.74-0.49$ & $\mathrm{~T}$ & 0 & 0 & 0 \\
\hline & $0.48-0.23$ & $\mathrm{R}$ & 0 & 0 & 0 \\
\hline & $<0.22$ & SR & 0 & 0 & 0 \\
\hline
\end{tabular}

Selatan Bali membentuk hubungan berupa asosiasi positif dan asosiasi tidak jelas. Menurut Kurniawan et al.(2008) asosiasi positif terjadi apabila suatu jenis biota hadir secara bersamaan dengan jenis biota lainnya dan tidak akan terbentuk tanpa adanya jenis biota lainnya tersebut. Asosiasi tidak jelas terjadi apabila ada faktor lain baik itu berupa ekosistem lain ataupun organisme lain.

Asosiasi yang ditemukan antara spesies lamun dengan ikan pada lokasi penelitian didominasi oleh asosisasi dengan kategori tidak jelas. Hal ini menunjukan bahwa spesies lamun dan ikan di perairan Selatan Bali menunjukan adanya faktor lain yang mempengaruhi asosiasi antara ikan dan lamun, dan faktor lain tersebut menimbulkan toleransi untuk hidup bersama.

\section{Pembahasan}

Lamun dan Ikan di selatan Bali banyak dipengaruhi oleh struktur penutupan lamun yang hidup disana dan ekosistem terumbu karang dan Mangrove yang letaknya berdekatan dengan ekosistem lamun (Pogoreutz et.al, 2012). Disekitar lokasi studi terdapat ekosistem terumbu karang (As-syakur dan Wiyanto, 2016), dan hal ini didukung oleh banyaknya patahan karang yang banyak tersebar di daerah tempat lamun tumbuh serta posisi lokasi studi yang juga berdekatan dengan ekosistem mangrove Bali Selatan, yaitu hutan mangrove di Teluk Benoa (Wiyanto dan Faiqoh, 2015). Akan tetapi karena adanya lamun yang tumbuh diperairan Bali Selatan, maka substratnya menjadi lebih lunak. Seperti yang diungkapkan oleh Campagne et al. (2015), lamun mampu menstabilkan dasar perairan yang lunak, melalui pengaruh sistem perakaran yang padat dan saling menyilang.

Pada penelitian ini, ukuran ikan yang ditemukan masih dalam usia juvenile. Ikan usia juvenile memanfaatkan lamun serta ekosistem terumbu karang dan ekosistem mangrove sebagai tempat berlindung dari predator. Selain itu juga ikan juvenile yang didapatkan pada ekosistem padang lamun ini tidak secara langsung menjadikan lamun sebagai bahan makanannya, namun memakan biota laut yang berasosiasi pada ekosistem lamun seperti larva, bivalvia, gastropoda, cephalopoda atau berbagai jenis zooplankton (Latuconsina dkk., 2012). Hal yang sama juga dikatakan oleh Pereira et al (2010), padang lamun digunakan oleh ikan juvenil dalam cara yang berbeda, umumnya sebagai situs pembibitan, tempat berlindung dari predator, mengurangi kompetisi dan meningkatkan ketersediaan sumber makanan, sehingga membangun hubungan konektivitas dengan ekosistem lainnya.

Keberadaan lamun yang beragam akan mempengaruhi keberagaman ikan dan juga jumlah kelimpahan ikan. Seperti yang ada pada Pantai Shindu, didapatkan lamun lebih beragam, yaitu 7 species, dari pada jumlah species lamun di pantai lain. Keberagaman ikan yang didapatkan juga lebih banyak di Pantai Shindu, yaitu 19 species, dari pada pantai lain. Hal ini sama seperti yang didapatkan Rappe (2010) di Pulau Barrang Lompo. Rappe mendapatkan 21 species pada daerah lamun yang padat multispecies. Hal yang sama juga dikatakan oleh Hori et al (2009), daerah lamun yang memiliki keanekaragaman yang tinggi lebih mempengaruhi kelimpahan dan keanekaragaman ikan daripada daerah lamun 
dengan keanekaragaman rendah. Shoji and Morimoto (2016) menambahkan, keanekaragaman dan kelimpahan ikan di padang lamun biasanya lebih tinggi daripada yang berdekatan dengan substrat kosong. Ditambahkan pula, Kumpulan ikan dari padang lamun yang berbeda seringkali berbeda juga (Unsworth, 2009) walaupun dua habitat itu berdekatan. Karena itu, jenis ikan yang didapatkan di Pantai Serangan, Pantai Shindu dan Pantai Samuh hanya sedikit yang jenisnya sama.

Kedekatan antara ekosistem lamun dan ekosistem terumbu karang yang berdekatan di semua pantai Selatan Bali dapat terlihat dari banyaknya ikan major terumbu karang yang hidup di daerah lamun. Hasil yang sama didapatkan oleh Cole et al. (2013), dimana pada stasiun penelitian yang dekat dengan daerah terumbu karang, didapatkan spesies ikan yang lebih banyak dibandingkan dengan stasiun lainnya. Shoji and Morimoto (2016) mengatakan hubungan kuat akan terjadi antara ekosistem lamun dengan habitat yang berbatasan, baik itu terumbu karang, mangrove ataupun estuari, dan habitat terdekat tersebut akan mempengaruhi komposisi jenis dan kelimpahan ikan yang hidup di daerah ekosistem lamun.

Kehadiran ikan di daerah padang lamun dapat bersifat temporal, dengan melihat padang lamun sebagai jalur migrasi ikan daerah mangrove dan terumbu karang, ikan yang sedang melakukan migrasi tersebut dapat tertangkap jaring ketika dilakukan sampling. Latuconsina dkk. (2012) dan Latuconsina dan Rappe (2013) mengatakan, keberadaan ikan di padang lamun dapat bersifat spasial dan temporal. Keberadaan spasial dapat dipengaruhi dari kepadatan lamunnya, sedangkan keberadaan temporal dipengaruhi oleh pasangsurut dan migrasi temporal.

Dari hal tersebut di atas, maka dapat sudah menjelaskan berdasarkan hasil perhitungan indeks asosiasi, jenis asosiasi antara lamun dengan ikan didominasi oleh asosiasi tidak jelas. Karena habitat yang berbatasan, seperti lamun dan terumbu karang serta lamun dan mangrove, sangat berperan besar terhadap keberadaan ikan di ekosistem lamun. Keberadaan ikan di lamun dapat memberi dampak positif, seperti yang dikatakan oleh Christianen et al. (2012) ikan herbivora yang memakan lamun dapat mengubah produktifitas, biomassa, distribusi, struktur komunitas dan kandungan nutrient di dalam lamun dan dengan pemakanan ikan herbivora tersebut dapat menambah pengkayaan nutrient di dalam ekosistem.

\section{Simpulan}

Komposisi jenis lamun yang didapatkan Pantai Samuh terdapat 6 jenis lamun, Enhalus acoroides, Thalassia hemprichii, Cymodocea rotundata, Halophila ovalis, Halodule uninervis, Halodule pinifolia. Komposisi jenis lamun yang didapatkan pada Pantai Shindu terdapat 7 jenis Enhalus acoroides, Thallasia hemprichii, Syringodium isoetifolium, Cymodocea rotundata, Halophila ovalis, Halodule uninervis, H. pinifolia; dan komposisi jenis lamun yang didapatkan di Pantai Serangan terdapat tiga jenis yaitu Syringodium isoetifolium, Cymodocea rotundata, C. serrulata.

Jenis lamun Cymodocea rotundata dan Syringodium isoetifolium banyak ditemukan di Pantai Serangan. Di Pantai Shindu, lamun yang banyak ditemukan adalah Syringodium isoetifolium dan Cymodocea rotundata, sedangkan di Pantai Samuh, jenis Thalassia hemprichii paling banyak dijumpai. Komposisi ikan karang yang didapatkan terdiri dari 21 Famili dengan family yang didapatkan species terbanyak adalah Family Pomacentridae, yaitu sebanyak 13 species. Jumlah total species dari tiga pantai adalah 37 species dengan masing-masing pantai, Pantai Samuh ditemukan 10 jenis, Pantai Serangan ditemukan 14 jenis dan di Pantai Shindu ditemukan 19 jenis. Kelimpahan ikan total terbesar didapatkan pada Pantai Shindu yaitu 0.172 ind $/ \mathrm{m}^{2}$, kemudian Pantai Samuh sebanyak 0.08 ind $/ \mathrm{m}^{2}$ dan Pantai Serangan sebanyak $0.016 \mathrm{ind} / \mathrm{m}^{2}$. Hasil perhitungan indeks asosiasi, jenis asosiasi antara lamun dengan ikan didominasi oleh asosiasi tidak jelas. Karena habitat yang berbatasan sangat berperan besar terhadap keberadaan ikan di ekosistem lamun.

\section{Ucapan terimakasih}

Penulis mengucapkan terimakasih sebesarbesarnya kepada Ratih, Anassita, Dika, Trisna, Dhananjaya, Arifin dan Fakhrizal setiawan yang telah membantu penelitian ini, khususnya saat proses pengambilan data dan analisis data di laboratorium.

\section{Daftar Pustaka}

As-syakur, A. R., \& Wiyanto, D. B. (2016). Studi kondisi hidrologis sebagai lokasi penempatan terumbu 
buatan di perairan Tanjung Benoa Bali. Jurnal Kelautan: Indonesian Journal of Marine Science and Technology, 9(1), 85-92.

Azkab, M. H. (2006). Ada apa dengan lamun. Majalah semi populer oseana, 31(3), 45-55.

Bass, J. I. F., Diallo, A., Nelson, J., Soto, J. M., Myers, C. L., \& Walhout, A. J. (2013). Using networks to measure similarity between genes: association index selection. Nature methods, 10(12), 1169-1176.

Bengen, D. G. (2001). Ekologi dan sumberdaya pesisir dan laut serta pengelolaannya secara terpadu dan berkelanjutan. Dalam Prosiding Pengelolaan Wilayah Pesisir Terpadu. Bogor-Indonesia, 23 Oktober - 3 November 2001.

Campagne, C. S., Salles, J. M., Boissery, P., \& Deter, J. (2015). The seagrass Posidonia oceanica: ecosystem services identification and economic evaluation of goods and benefits. Marine pollution bulletin, 97(1), 391-400.

Christianen, M. J., Govers, L. L., Bouma, T. J., Kiswara, W., Roelofs, J. G., Lamers, L. P., \& van Katwijk, M. M. (2012). Marine megaherbivore grazing may increase seagrass tolerance to high nutrient loads. Journal of Ecology, 100(2), 546-560.

Cole, A. J., Pratchett, M. S., \& Jones, G. P. (2008). Diversity and functional importance of coral feeding fishes on tropical coral reefs. Fish and Fisheries, 9(3), 286-307.

Heck, K. L., Carruthers, T. J., Duarte, C. M., Hughes, A. R., Kendrick, G., Orth, R. J., \& Williams, S. W. (2008). Trophic transfers from seagrass meadows subsidize diverse marine and terrestrial consumers. Ecosystems, 11(7), 1198-1210.

Hejda, M., Pyšek, P., \& Jarošík, V. (2009). Impact of invasive plants on the species richness, diversity and composition of invaded communities. Journal of Ecology, 97(3), 393-403.

Hori, M., Suzuki, T., Monthum, Y., Srisombat, T., Tanaka, Y., Nakaoka, M., \& Mukai, H. (2009). High seagrass diversity and canopy-height increase associated fish diversity and abundance. Marine Biology, 156(7), 14471458.

Menristek. (2010). Keputusan Menteri Riset dan Teknologi Republik Indonesia No.193/M/Kp/IV/2010 tentang Kebijakan Strategis Pembangunan Nasional Ilmu Pengetahuan dan Teknologi 2010-2014. Jakarta, Indonesia: Kementerian Riset dan Teknologi Republik Indonesia.

Kurniawan, A., Undaharta, N. K. E., \& Pendit, I. M. R. (2008). Asosiasi Jenis-Jenis Pohon Dominan Di Hutan Dataran Rendah Cagar Alam Tangkoko, Bitung, Sulawesi Utara. Biodiversitas, 9(3), 199-203.
Latuconsina, H., \& Rappe, R. A. (2013). Variabilitas harian komunitas ikan padang lamun perairan Tanjung Tiram-Teluk Ambon Dalam. Jurnal Iktiologi Indonesia, 13(1), 35-53.

Latuconsina, H., Nessa, M. N., \& Rappe, R. A. (2012). Komposisi spesies dan struktur komunitas ikan padang lamun di perairan Tanjung Tiram-Teluk Ambon Dalam. Jurnal Ilmu dan Teknologi Kelautan Tropis, 4(1), 35-46.

Nontji, A. (2009). Rehabilitasi ekosistem lamun dalam pengelolaan sumberdaya pesisir. Dalam Lokakarya Nasional 1 Pengelolaan Ekosistem Lamun. JakartaIndonesia, 18 November 2009.

Nordlund, L., Erlandsson, J., de la Torre-Castro, M., \& Jiddawi, N. (2010). Changes in an East African socialecological seagrass system: invertebrate harvesting affecting species composition and local livelihood. Aquatic Living Resources, 23(4), 399-416.

Pereira, P. H., Ferreira, B. P., \& Rezende, S. M. (2010). Community structure of the ichthyofauna associated with seagrass beds (Halodule wrightii) in Formoso River estuary-Pernambuco, Brazil. Anais da academia Brasileira de Ciencias, 82(3), 617-628.

Rappe, R. A. (2010). Struktur Komunitas Ikan Pada Padang Lamun yang Berbeda di Pulau Barrang Lompo. Jurnal Ilmu dan Teknologi Kelautan Tropis, 2(2), 62-73.

Rappe, R. A., Nessa, M. N., Latuconsina, H., \& Lajus, D. L. (2013). Relationship between the tropical seagrass bed characteristics and the structure of the associated fish community. Open Journal of Ecology, 3(5), 331-342.

Pogoreutz, C., Kneer, D., Litaay, M., Asmus, H., \& Ahnelt, H. (2012). The influence of canopy structure and tidal level on fish assemblages in tropical Southeast Asian seagrass meadows. Estuarine, Coastal and Shelf Science, 107, 58-68.

Shoji, J., \& Morimoto, M. (2016). Changes in fish community in seagrass beds in Mangoku-ura Bay from 2009 to 2014, the period before and after the tsunami following the 2011 off the Pacific coast of Tohoku earthquake. Journal of oceanography, 72(1), 9198.

Unsworth, R. K., Garrard, S. L., De León, P. S., Cullen, L. C., Smith, D. J., Sloman, K. A., \& Bell, J. J. (2009). Structuring of Indo-Pacific fish assemblages along the mangrove-seagrass continuum. Aquatic Biology, 5(1), 85-95.

Wiyanto, D. B., \& Faiqoh, E. (2015). Analisis vegetasi dan struktur komunitas Mangrove Di Teluk Benoa, Bali. Journal of Marine and Aquatic Sciences, 1(1), 1-7.

(C) 2017 by the authors; licensee Udayana University, Indonesia. This article is an open access article distributed under the terms and conditions of the Creative Commons Attribution license (http://creativecommons.org/licenses/by/3.0/). 